Fukushima J. Med. Sci.,

Vol. 57, No. 2, 2011

[Original Article]

\title{
EFFECT OF ADDITIONAL ADMINISTRATION OF TACROLIMUS IN PATIENTS WITH RHEUMATOID ARTHRITIS TREATED WITH BIOLOGICS
}

\author{
MASAYUKI MIYATA, TOMOYUKI ASANO and SHUZO SATOH \\ Department of Internal Medicine, Fukushima Red Cross Hospital, Fukushima-City, Fukushima, Japan
}

(Received April 11, 2011, accepted August 19, 2011)

\begin{abstract}
:
Objective : To explore the effect of additional administration of tacrolimus to rheumatoid arthritis patients treated with biologics, in whom the effect of biologics is unsatisfactory.

Methods : Tacrolimus was administered if the effect of biologics was unsatisfactory for 24 weeks at least in terms of laboratory data or DAS28 level : ESR, CRP level and DAS28 level were not below $15 \mathrm{~mm} / \mathrm{h}, 0.2 \mathrm{mg} / \mathrm{dl}$ or 2.6 , respectively.

Results : Tacrolimus administered in addition to biologics was significantly effective for suppressing the activity of rheumatoid arthritis in our study. The significant effect of tacrolimus appeared at the $4^{\text {th }}$ week. The effect of tacrolimus achieved quite significant level at the $54^{\text {th }}$ week $(p<0.0001)$.
\end{abstract}

Conclusion : Tacrolimus may be a promising candidate to suppress the disease activity of rheumatoid arthritis refractory to the conventional treatment with biologics.

Key words : biologics, coadministration, rheumatoid arthritis, tacrolimus

\section{INTRODUCTION}

T-cell activation is critical to the onset and perpetuation of rheumatoid arthritis (RA) $)^{1)}$ Tacrolimus (Tac) exerts its immunosuppressive effects by inhibiting of calcineurin, leading to interference with T-cell activation and proliferation ${ }^{2}$. As T-cell activation plays a major role in the pathogenesis of RA, there has been interest in the use of Tac for the treatment of $\mathrm{RA}^{3)}$. Tac was approved in Japan for the treatment of RA in 2005.

There are some patients with RA treated with biologics, in whom the effect of biologics is unsatisfactory. We explored the effect of additional administration of Tac to patients treated with biologics, in whom the effect of biologics is unsatisfactory.

\section{MATERIALS AND METHODS}

Patients were enrolled in the study if they met the American College of Rheumatology 1987 crite$\mathrm{ria}^{4)}$. Disease activity and clinical response were evaluated on the basis of DAS28 (disease activity score of 28 joints) and EULAR (European League Against Rheumatism) response criteria ${ }^{5,6)}$, respectively. Methotrexate (MTX) was administered up to $8 \mathrm{mg} /$ week. The approved MTX dose is up to 8 $\mathrm{mg} /$ week in Japan. Biologics such as infliximab or etanercept were administered in accordance with the instructions file attached to these medicines.

If the effect of biologics was unsatisfactory for 24 weeks at least in terms of laboratory data or DAS28 level : ESR, CRP level or DAS28 level were not below $15 \mathrm{~mm} / \mathrm{h}, 0.2 \mathrm{mg} / \mathrm{dl}$ or 2.6 , respectively, we considered to coadministrate Tac to the biologics. The starting dose was $1 \mathrm{mg} /$ day once daily after dinner, then the dose was increased up to 3 mg. To avoid side effects such as infection and gastrointestinal symptoms, the dose of Tac was kept as low as possible.

宮田昌之, 浅野智之, 佐藤秀三

Correspondence and reprint requests to Masayuki Miyata, MD, PhD E-mail adress : metm@nifty.com http://www.jstage.jst.go.jp/browse/fms http://fmu.ac.jp/home/lib/F-igaku/ 
The patients visited our clinic every 4 weeks, and the observation period to determine the effect of the additional administration of Tac on the biologic treatment was at least 12 weeks, and the observation period was extended up to 54 weeks if the additional administration of Tac was effective.

Data were expressed as the mean \pm standard deviation. Data obtained at a specified time were compared with those obtained at baseline or other times using the Wilcoxon signed-rank test. The significance level was $p<0.05$.

\section{RESULTS}

The results on the effect of additional administration of Tac in patients with RA treated with biologics are shown in Table 1. Sixteen infliximabtreated patients and 12 etanercept-treated patients were enrolled in this study. The mean doses of MTX administered to the patients treated with infliximab and those with etanercept were $7.6(4 \sim 8)$ and 5.0 $(0 \sim 8) \mathrm{mg}$, respectively. The mean doses of Tac administered to the patients treated with infliximab and those with etanercept were 1.56(1 2) and 1.33(1 2) mg, respectively.

Table 1. Baseline characteristics of patients treated with combination of biologics and tacrolimus

\begin{tabular}{ccccccc}
\hline & sex & age & $\begin{array}{c}\text { Steinbrocker } \\
\text { stage }\end{array}$ & $\begin{array}{c}\text { Steinbrocker } \\
\text { class }\end{array}$ & $\begin{array}{c}\text { dose of } \\
\text { MTX }^{\S}(\mathrm{mg})\end{array}$ & $\begin{array}{c}\text { final dose of } \\
\text { Tacrolimus }(\mathrm{mg})\end{array}$ \\
\hline $\begin{array}{c}16 \text { patients } \\
\text { treated with IFX } \\
\begin{array}{c}12 \text { patients } \\
\text { treated with ETN }\end{array}\end{array}$ & $\mathrm{F}: \mathrm{M}: \mathrm{M}=8: 4$ & 66.3 & III & 2.1 & $7.6(4 \sim 8)$ & $1.56(1 \sim 2)$ \\
\hline
\end{tabular}

Data are expressed as mean.

IFX, infliximab ; ETN, etanercept

${ }^{\S}$ MTX, methotrexate

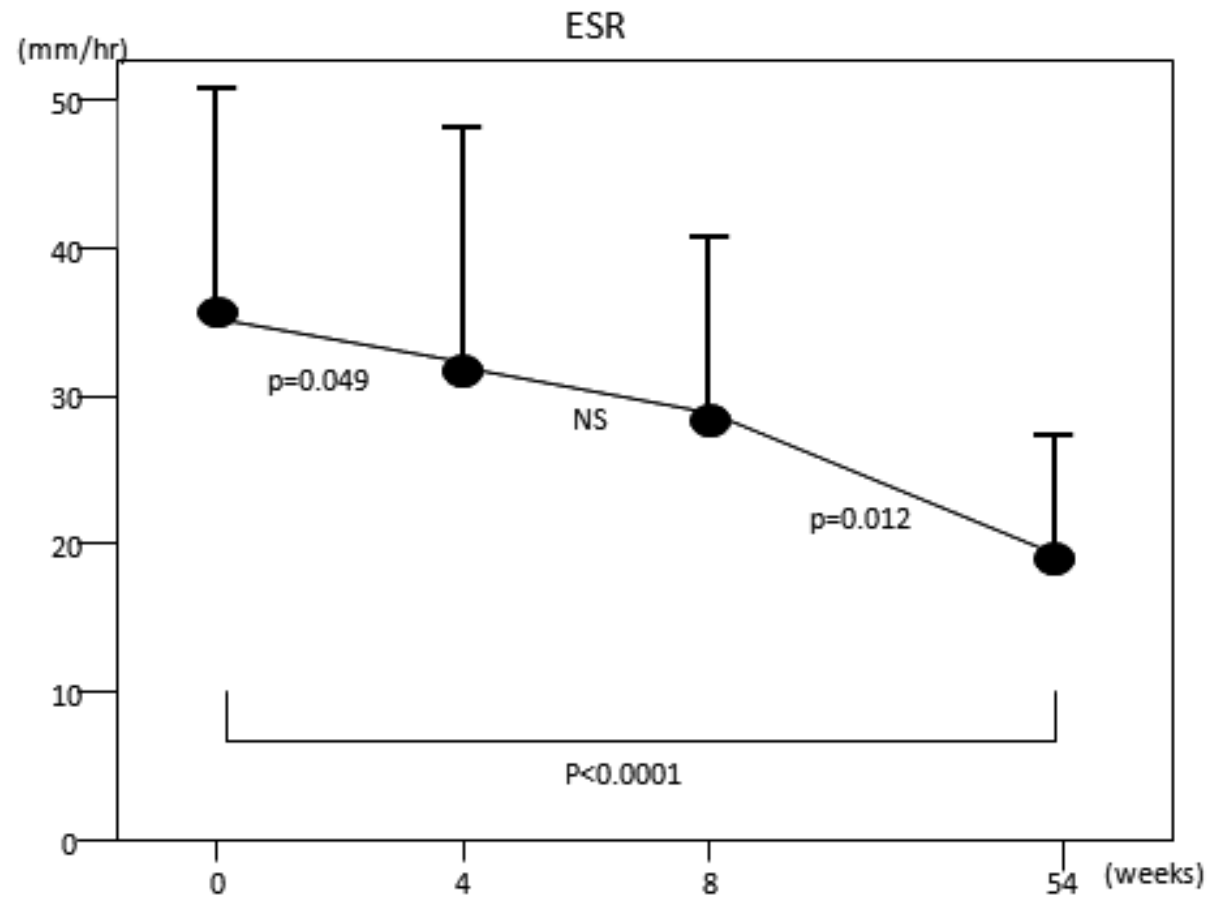

Fig. 1. ESR levels in the first three visits $\left(0,4,8^{\text {th }}\right.$ week $)$, and that of $54^{\text {th }}$ week.

ESR level significantly decreased from $37 \pm 17$ to $32 \pm 18$ at the $4^{\text {th }}$ week $(p=0.049)$. However, there was no significant difference between ESR level of the $4^{\text {th }}$ week and that of the $8^{\text {th }}$ week.

ESR level significantly decreased from $29 \pm 16$ at $8^{\text {th }}$ week to $18 \pm 12$ at $54^{\text {th }}$ week $(p=0.012)$.

ESR level significantly decreased from week 0 to $54^{\text {th }}$ week $(p<0.0001)$.

Data are expressed as mean \pm SD. 


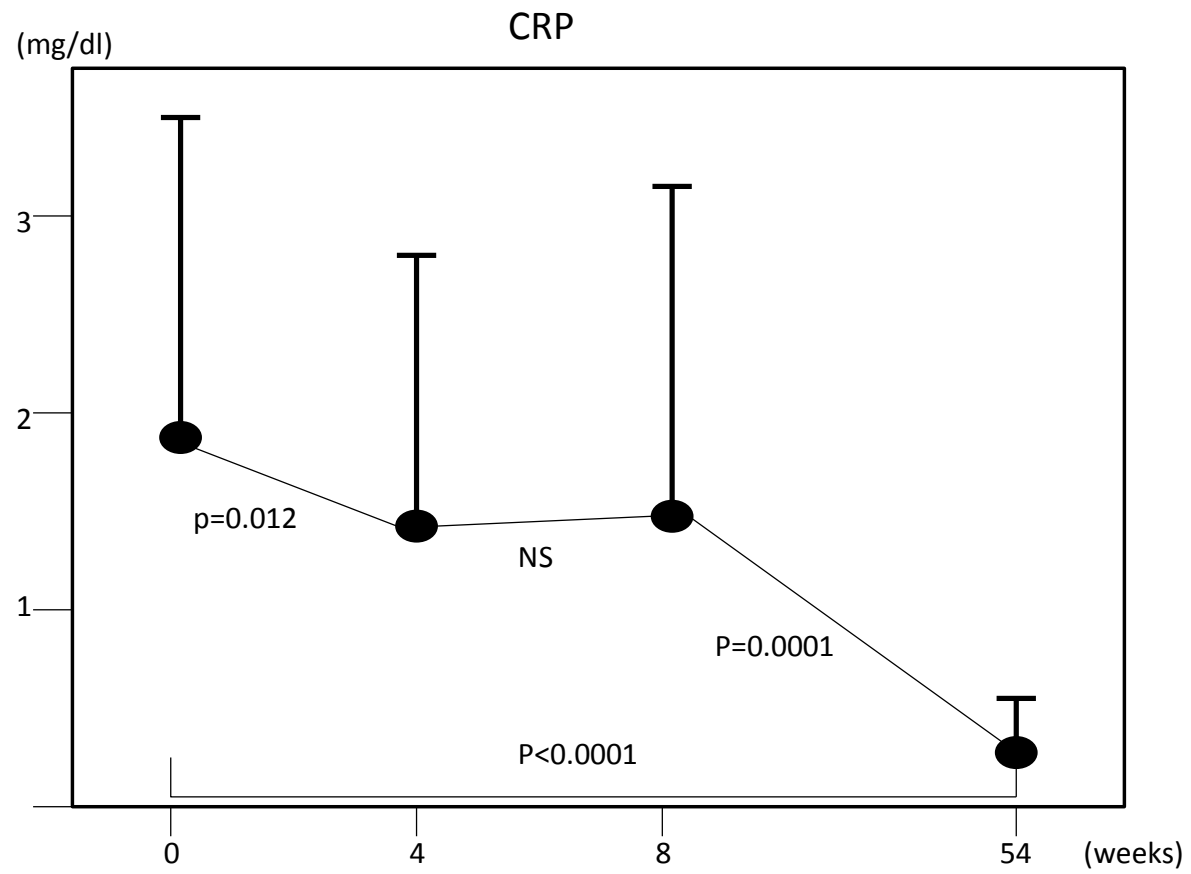

Fig. 2. CRP levels in the first three visits $\left(0,4,8^{\text {th }}\right.$ week), and that at $54^{\text {th }}$ week.

CRP level significantly decreased from $1.9 \pm 1.5$ to $1.4 \pm 1.5$ at the $4^{\text {th }}$ week $(p=0.012)$. However, there was no significant difference between CRP level of $4^{\text {th }}$ week and that of the $8^{\text {th }}$ week.

CRP level significantly decreased from $1.6 \pm 1.9$ at $8^{\text {th }}$ week to $0.27 \pm 0.26$ at $54^{\text {th }}$ week $(p=0.0001)$.

CRP level significantly decreased from week 0 to $54^{\text {th }}$ week $(\phi<0.0001)$.

Data are expressed as mean \pm SD.

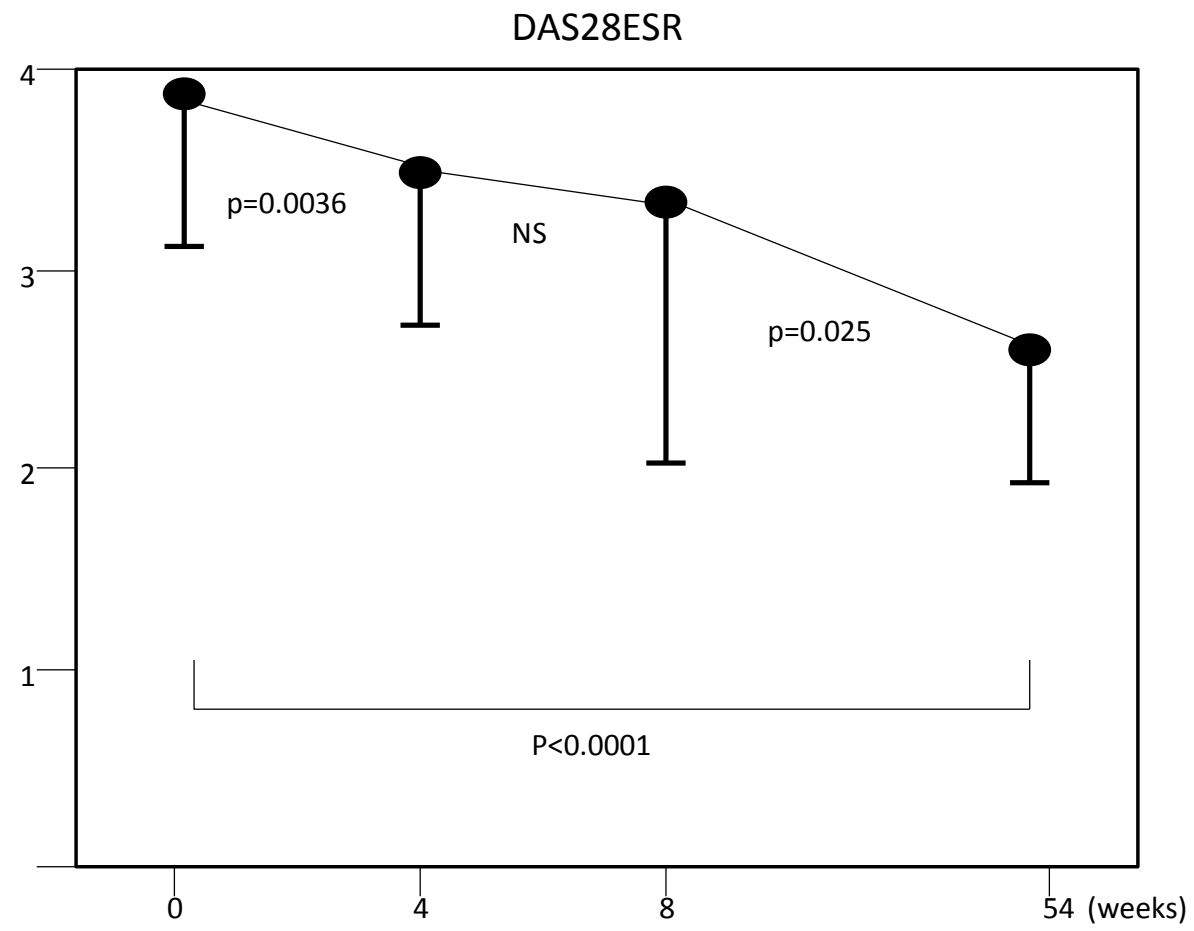

Fig. 3. DAS28ESR levels in the first three visits $\left(0,4,8^{\text {th }}\right.$ week), and that at $54^{\text {th }}$ week.

DAS28ESR level significantly decreased from $4.0 \pm 0.88$ to $3.5 \pm 0.85$ at the $4^{\text {the }}$ week $(p=0.0036)$. However, there was no significant difference between DAS28ESR level of the $4^{\text {the }}$ week and that of the $8^{\text {th }}$ week. DAS28ESR level significantly decreased from $3.3 \pm 1.2$ at $8^{\text {th }}$ week to $2.6 \pm 0.67$ at $54^{\text {th }}$ week $(p=0.025)$. DAS28ESR level significantly decreased from week 0 to $54^{\text {th }}$ week $(p<0.0001)$.

Data are expressed as mean $\pm \mathrm{SD}$. 


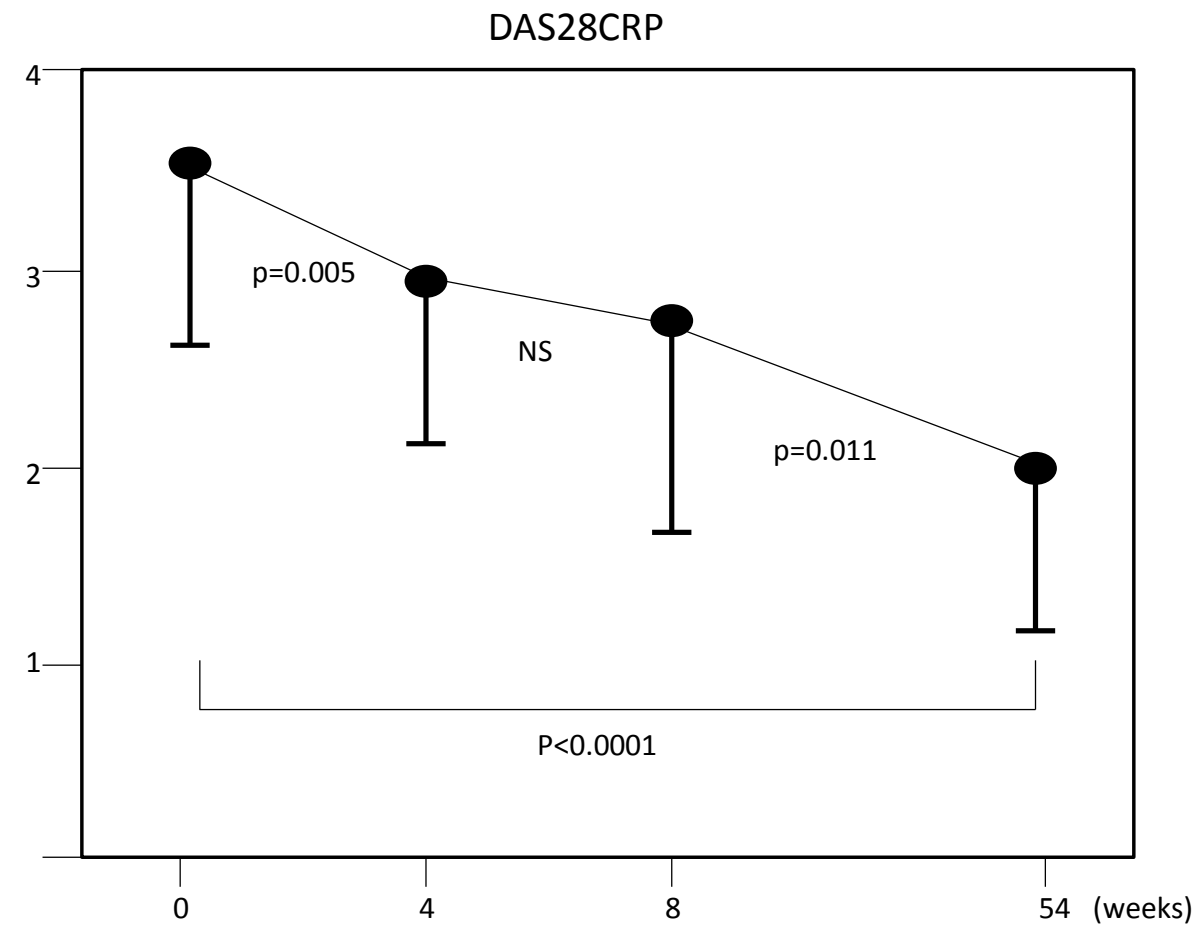

Fig. 4. DAS28CRP levels in the first three visits $\left(0,4,8^{\text {th }}\right.$ week $)$, and that at $54^{\text {th }}$ week.

DAS28CRP level significantly decreased from $3.5 \pm 0.94$ to $2.9 \pm 0.89$ at the $4^{\text {th }}$ week $(p=0.005)$. However, there was no significant difference between DAS28CRP level of the $4^{\text {th }}$ week and that of the $8^{\text {th }}$ week.

DAS28CRP level significantly decreased from $2.8 \pm 1.0$ at $8^{\text {th }}$ week to $2.0 \pm 0.73$ at $54^{\text {th }}$ week $(p=0.011)$.

DAS28CRP level significantly decreased from week 0 to $54^{\text {th }}$ week $(p<0.0001)$.

Data are expressed as mean $\pm \mathrm{SD}$.

The first three visits $\left(0,4,8^{\text {th }}\right.$ week) to the hospital after administration of Tac were chosen as the times in which we determined ESR, CRP levels, DAS28ESR and DAS28CRP levels.

Figure 1 and 2 show ESR and CRP levels in the first three visits to the hospital, respectively. The mean ESR and CRP levels determined in the patients at the initiation of Tac treatment were $37 \pm 17 \mathrm{~mm} / \mathrm{hr}$ and $1.9 \pm 1.5 \mathrm{mg} / \mathrm{dl}$, respectively.

ESR and CRP levels significantly decreased from $37 \pm 17$ to $32 \pm 18$ and from $1.9 \pm 1.5$ to $1.4 \pm 1.5$, respectively, at the $4^{\text {th }}$ week $(p=0.049$ and $p=0.012$, respectively). However, both did not decrease significantly from the levels of the $4^{\text {th }}$ week to those of the $8^{\text {th }}$ week.

Figure 3 and 4 show the DAS28ESR and DAS28CRP levels in the first three visitis, respectively. The mean DAS28ESR and DAS28CRP levels determined in the patients at the initiation of Tac treatment were $4.0 \pm 0.88$ and $3.5 \pm 0.94$, respectively.

DAS28ESR and DAS28CRP levels decreased from $4.0 \pm 0.88$ to $3.5 \pm 0.85$ and from $3.5 \pm 0.94$ to $2.9 \pm 0.89$, respectively, at the $4^{\text {th }}$ week $(p=0.0036$ and $p=0.005$, respectively). However, both did not decrease significantly from the levels of $4^{\text {th }}$ week to those of the $8^{\text {th }}$ week.

Obviously, ESR, CRP level, DAS28ESR and DAS28CRP levels significantly decreased at the $4^{\text {th }}$ week.

The additional administration of Tac was effective as determined on the basis of DAS28ESR level according to EULAR response criteria, in 11 out of 16 RA patients (good,10; moderate,1) when combined with infliximab, and in 10 out of $12 \mathrm{RA}$ patients (good,9 ; moderate,1) when combined with etanercept. In other words, the additional administration of Tac showed no effect on 5 out of 16 patients treated with infliximab, and 2 out of 12 patients treated with etanercept.

The observation period was extended up to 54 weeks if the additional administration of Tac was effective, and 25 out of 28 patients were enrolled in this study. Three out of 28 patients changed the biologics. Two out of the three patients changed the biologics because the additional administration of Tac was not effective. One out of the three patients changed the biologics because she wished becoming pregnant.

As shown in Figure 1 and 2, ESR and CRP lev- 
els significantly decreased from $8^{\text {th }}$ week to $54^{\text {th }}$ week, respectively. $(p=0.012$ and $p=0.0001$, respectively).

As shown in Figure 3 and 4, DAS28ESR and DAS28CRP levels significantly decreased from $8^{\text {th }}$ week to $54^{\text {th }}$ week, respectively. $\quad(p=0.025$ and $p=0.011$, respectively).

Nine out of 28 patients and 11 out of 25 patients achieved remission using the criteria DAS28ESR $<2.6^{7,8)}$ at $8^{\text {th }}$ week and at $54^{\text {th }}$ week, respectively.

Eleven out of 28 patients and 20 out of 25 patients achieved remission using the criteria DAS28CRP $<2.3^{7,8)}$ at $8^{\text {th }}$ week and at $54^{\text {th }}$ week, respectively.

No serious adverse event was observed in these patients during the observation period.

\section{DISCUSSION}

Weekly MTX administration is gold standard in RA therapy. The dose approved in Japan is up to 8 $\mathrm{mg} /$ week, which is lower than that used in the US and European countries. However, in our experience, the dose of MTX has to be decreased sometimes to less than $8 \mathrm{mg} /$ week because of complications in patients such as leucopenia, refractory cough and nausea. Moreover, a certain proportion of RA patients are resistant and/or intolerant to MTX.

Biologics exhibit significant anti-inflammatory and anti-rheumatic effects. However, not all RA patients show a good response to biologics ${ }^{9)}$.

Interestingly, it has been demonstrated that the Th1 : Th2 ratio in the peripheral blood is raised following infliximab treatment ${ }^{10)}$. From this point of view, treatment with biologics and/or MTX lacks T-cell-targeted immunosuppression. Tac excerts its immunosuppressive effect primarily by interfering with the activation of T-cells. Tac also suppresses the production of cytokines such as IL-2 and $\mathrm{TNF} \alpha^{11,12)}$. The usefulness of Tac for RA has been demonstrated in double-blind, placebo-controlled, parallel-group studies and controlled studies compared with other drugs ${ }^{13,14)}$. Tac up to $3 \mathrm{mg}$ /daily is approved to be used for the patients with RA in Japan.

Efficacy of low-dose Tac added to MTX in patients with RA in Japan was demonstrated in retrospective study ${ }^{15)}$. Interestingly, 2 patients, in whom the effect of Tac was unsatisfactory in combination with etanercept, were not prescibed MTX.

Additional administration of Tac to the treatment with biologics was significantly effective to suppress the activity of RA in our study. The effect appeared at $4^{\text {th }}$ week. Therefore, if no improvement is observed 4 weeks after the treatment with the combination of a biologic and Tac, one should consider whether to continue the combination therapy or not.

Presently in Japan, three TNF inhibitors and one interleukin- 6 inhibitor are available to physicians. We have options to increase the dose of infliximab and/or shorten the interval of infliximab administration. Moreover, we can switch from one biologic to another. However, these alterations of treatment are sometimes troublesome and are sometimes invalid. The strategy to add Tac is easy to carry out without changing the dose and/or interval of biologic administration. Therefore, if the effect of biologics is unsatisfactory, we should consider the addition of Tac.

Quite recently, increase of MTX dose up to 16 $\mathrm{mg} /$ week has been approved in Japan. The difference of addition of Tac and increase of the MTX dose should be compared in terms of its effect.

In order to avoid side effects due to immunosuppression, the dose of Tac was limited to be as low as possible. Side effects such as pneumonia were not observed in the patients enrolled in this study. The occurrence of infection and neoplasm should be carefully examined in the future.

The nuclear factor of activated T-cells (NFAT) is a regulator of osteoclastogenesis and is induced by RANKL ${ }^{16)}$. Tac inhibits osteoclast formation by targeting the NFAT/calcineurin pathway ${ }^{17}$. The effect of prevention of bone destruction by this combination therapy is promising; however, the effect of suppression of the destruction of the joint has not been determined yet. Tac may be a promising candidate to suppress activity of RA refractory to the conventional treatment with biologics.

No conflict of interest exists in this study.

\section{REFERENCES}

1. Moreland LW, Heck LW Jr, Koopman WJ. Biologic agents for treating rheumatoid arthritis. Concepts and progress. Arthritis Rheum, $40: 397-$ 409, 1997.

2. Liu J, Farmer JD Jr, Lane WS, Friedman J, Weissman I, Schreiber SL. Calcineurin is a common target of cyclophilin-cyclosporin A and FKBP-FK506 complexes. Cell, 66 : 807-815, 1991.

3. Fleischmann R, Iqbal I, Stern RL. Tacrolimus in rheumatoid arthritis. Expert Opin Pharmacother, 
$7:$ 91-98, 2006.

4. Arnett FC, Edworthy SM, Bloch DA, McShane DJ, Fries JF, Cooper NS, et al. The American Rheumatism Association 1987 revised criteria for the classification of rheumatoid arthritis. Arthritis Rheum, 31 : 315-324, 1988.

5. van der Heijde DM, van 't Hof MA, van Riel PL, Theunisse LA, Lubberts EW, van Leeuwen MA et al. Judging disease activity in clinical practice in rheumatoid arthritis : first step in the development of a disease activity score. Ann Rheum Dis, 49 : 916-920, 1990.

6. van Gestel AM, Prevoo ML, van't Hof MA, van Rijswijk MH, van de Putte LB, van Riel PL. Development and validation of the European League Against Rheumatism response criteria for rheumatoid arthritis. Comparison with the preliminary American College of Rheumatology and the World Health Organization/International League Against Rheumatism Criteria. Arthritis Rheum, 39 : 34-40, 1996.

7. Fransen J, Creemers MC, Van Riel PL. Remission in rheumatoid arthritis : agreement of the disease activity score (DAS28) with the ARA preliminary remission criteria. Rheumatology (Oxford). 43 : 1252-1255, 2004.

8. Matsui T, Kuga Y, Kaneko A, Nishino J, Eto Y, Chiba N, et al. Disease Activity Score 28 (DAS28) using $\mathrm{C}$-reactive protein underestimates disease activity and overestimates EULAR response criteria compared with DAS28 using erythrocyte sedimentation rate in a large observational cohort of rheumatoid arthritis patients in Japan. Ann Rheum Dis, 66 : 1221-1226, 2007.

9. Buch $\mathrm{MH}$, Marzo-Ortega H, Bingham SJ, Emery P. Long-term treatment of rheumatoid arthritis with tumour necrosis factor alpha blockade: outcome of ceasing and restarting biologicals. Rheumatology, Oxford, 43 : 243-244, 2004.

10. Maurice MM, van der Graaff WL, Leow A, Breedveld FC, van Lier RA, Verweij CL. Treatment with monoclonal anti-tumor necrosis factor alpha antibody results in an accumulation of Th1 CD4+ $\mathrm{T}$ cells in the peripheral blood of patients with rheumatoid arthritis. Arthritis Rheum, 42: 2166-2173, 1999.

11. Hatanaka H, Kino T, Miyata S, Inamura N, Kuroda A, Goto T, et al. FR-900520 and FR-900523, novel immunosuppressants isolated from a Streptomyces. II. Fermentation, isolation and physico-chemical and biological characteristics. J Antibiot, Tokyo, 41 : 1592-1601, 1988.

12. Kelly PA, Burckart GJ, Venkataramanan R. Tacrolimus : a new immunosuppressive agent (Review) Am J Health Syst Pharm, 52 : 1521-1535, 1995.

13. Furst DE, Saag K, Fleischmann MR, Sherrer Y, Block JA, Schnitzer T, et al. Efficacy of tacrolimus in rheumatoid arthritis patients who have been treated unsuccessfully with methotrexate : a sixmonth, double-blind, randomized, dose-ranging study. Arthritis Rheum, 46 : 2020-2028, 2002.

14. Yocum DE, Furst DE, Kaine JL, Baldassare AR, Stevenson JT, Borton MA, et al. Tacrolimus Rheumatoid Arthritis Study Group. Efficacy and safety of tacrolimus in patients with rheumatoid arthritis : a double-blind trial. Arthritis Rheum, 48: 3328-3337, 2003.

15. Morita Y, Sasae Y, Sakuta T, Satoh M, Sasaki T, Kashihara N. Efficacy of low-dose tacrolimus added to methotrexate in patients with rheumatoid arthritis in Japan: a retrospective study. Mod Rheumatol, 18 : 379-384, 2008.

16. Balkan W, Martinez AF, Fernandez I, Rodriguez MA, Pang M, Troen BR. Identification of NFAT binding sites that mediate stimulation of cathepsin $\mathrm{K}$ promoter activity by RANK ligand. Gene, 446: 90-98, 2009.

17. Miyazaki M, Fujikawa Y, Takita C, Tsumura H. Tacrolimus and cyclosporine A inhibit human osteoclast formation via targeting the calcineurindependent NFAT pathway and an activation pathway for c-Jun or MITF in rheumatoid arthritis. Clin Rheumatol, 26 : 231-239, 2007. 